\title{
Immunologist takes AIDS hot-seat at NIH
}

Washington. William Paul, an immunologist specializing in the formation of antibodies, will be named this week as the director of the upgraded Office of AIDS Research (OAR) at the US National Institutes of Health (NIH)

Paul, who is 57 years old and has long been head of the immunology laboratory at the National Institute of Allergy and Infectious Diseases (NIAID), will bring strong scientific credentials to the job. But he will also need political skills to handle a sensitive position, created at the behest of Congress under pressure from AIDS activist groups.

As director of the OAR, Paul will assume control of NIH's $\$ 1.4$ billion AIDS research budget. Until now, this control has been exercised by institute directors, such as NIAID's Tony Fauci. The activists claim there is evidence of "a pattern of resistance" at NIH to the new OAR, but Fauci describes this claim as "preposterous".

Paul was selected for the job by Harold Varmus, the director of NIH, who moved swiftly to fill the post after the previous front-runner, Bernard Fields, a Harvard virologist, withdrew for health reasons. "Paul

\section{France warned of laboratory 'spies'}

Paris. Scientists working for France's national biomedical research organization, INSERM, have been warned of the need to guard against the risks of 'scientific espionage' arising from the increasing internationalization of science and growing interest in its strategic importance.

The warning comes in an article published in the organization's in-house magazine INSERM Actualité, by Pierre Louisot, a laboratory director who is also responsible for INSERM's counterespionage activities.

Louisot says that scientific espionage by both foreign governments and foreign companies is now common in areas such as biotechnology, medical imagery and pharmaceuticals. He also claims that smaller powers keen to obtain the know-how to make biological and chemical weapons are targeting laboratories whose work would not usually be considered as sensitive to national defence.

Louisot says he is committed to scientific openness, but not to what he describes as scientific naivety. He claims that the idealistic urge of researchers to contribute to scientific knowledge is exploited by "more realistic" countries.

Scientists should think twice before making public results in sensitive areas, he says, claiming that more than 90 per cent of scientific espionage amounts simply to organized collection of information that is either published or presented at conferences, but that extra work is then put into filling the "gaps" in this knowledge.

In particular, Louisotclaims that researchers are easy prey to questions such as "What are you working on? What areas do you think are worth exploring?" Questionnaires putting such apparently benign questions, he claims, are often a front for organized intelligence gathering.

Increasing international collaboration in biology is also making France more vulnerable to both professional spies and scientists bribed by foreign countries or companies, claims Louisot. The threat is well controlled within France, he says; but Europe - at least in biology - is a "sieve".

Louisot claims that a scientific counterespionage policy is needed at the European level. The French counterespionage organization, the Direction de la Surveillance du Territoire (DST) recently launched its own

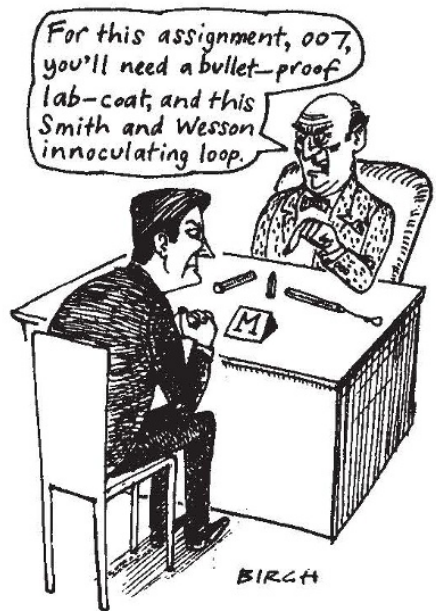

campaign to promote awareness of industrial espionage and scientific spying; it says that Europe's counterespionage organizations have discussed a joint strategy to protect the ECU8.84 billion Eureka European high-technology research programme.

Louisot claims that INSERM researchers have experienced every sort of espionage, although most of the incidents of which he is aware have been minor. He says that he does not want to create a reds-underthe-bench psychology among scientists, but merely to persuade them to become more vigilant and to take simple precautions such as not sending confidential information by fax or electronic mail, both of which can be easily intercepted by electronic eavesdroppers.
Declan Butler is a superb scientist who will bring fresh perspectives to the already substantial NIH effort against AIDS," says Varmus. "I am confident that he has the scientific acumen and leadership qualities needed to re-evaluate and shape our approach to AIDS."

Shortly before Paul's acceptance of the post, leading AIDS activists had written to Varmus's boss, Donna Shalala, the Secretary of Health, demanding a meeting to discuss what they described as "a set of problems that threaten to undermine the [Clinton] administration's major AIDS research initiative to date".

In particular, they claimed that opposition to the transfer of control of AIDS research funding from existing NIH institutes to the OAR - a move they claimed was necessary to stimulate new approaches to AIDS research - was threatening to undermine the new office, and deterring the best available candidates from applying for the directorship.

They quoted a letter to Varmus from one leading AIDS researcher (whose name is being withheld), declining an interview for the job and claiming the existence of a "powerful contingent" within NIH vehemently opposed to the revamped OAR. "Unless the political climate improves, it will be difficult to find a director who could survive, much less thrive, in such an environment," the letter said.

Varmus says he has asked for evidence to back up the allegation, and denies the existence of internal opposition to the new OAR. The chief target of the activists' suspicions is Fauci, who has been working as part-time director of the OAR, and whose institute carries out half of all AIDS research at NIH.

But Fauci says that the perception of resistance is "not founded at all" and that the facts speak for themselves. "You are going to see an extraordinary amount of pulling together to make [the OAR] work," says Fauci. "Let's look and see what happens."

The groups whose leaders wrote to Shalala include the National Minority AIDS Council, the Treatment Action Group in New York and the AIDS Action Council in Washington. They were instrumental in persuading Senator Edward Kennedy (Democrat, Massachusetts) and Representative Henry Waxman (Democrat, California) to frame legislation last summer giving the OAR new powers to oversee all AIDS research at NIH.

They are also concerned that the OAR may not receive the $\$ 100$ million annual funding that Kennedy and Waxman said it should have - it has been allocated $\$ 10$ million in the current financial year - and will fail to take effective control of the NIH AIDS budget during the financial year starting on 1 October, as Congress intended.

Colin Macilwain 